\title{
The Impact of Corpus-Based Collocation Instruction on Iranian EFL Learners' Collocation Learning
}

\author{
Shabnam Ashouri", Masoume Arjmandi, Ramin Rahimi \\ Department of English, Guilan Science and Research Branch, Islamic Azad University, Guilan, Iran \\ *Corresponding Author: arat_8285@yahoo.com
}

Copyright (C) 2014 Horizon Research Publishing All rights reserved.

\begin{abstract}
Over the past decades, studies of EFL/ESL vocabulary acquisition have identified the significance of collocations in language learning. Due to the fact that collocations have been regarded as one of the major concerns of both EFL teachers and learners for many years, the present study attempts to shed light on the impact of corpus-based collocation on EFL learners' collocation learning and awareness. 60 Iranian EFL learners, who participated in this study, were chosen randomly based on their scores in an OPT exam. There were two groups, experimental and control ones. The study examined the effects of direct corpus-based collocation instruction on EFL learners' collocation learning. For 15 sessions the control group received single-item vocabulary or, the usual work of their class and the experimental group received lexical collocation instruction as treatment. The same test as post-test was given to the learners when the treatment accomplished, and after that a t-test and kolmogorov-smirnov test between the pre-tests and post-tests were calculated. According to the results demonstrated by the statistical program, the effectiveness of the treatment was noticeable. This study suggests that direct corpus-based collocation instruction can be a worthy alternative. It demonstrated that the learners, who were in the experimental group, got aware of the existence of collocations, used them and learnt them properly, and they also started to find the collocation of every other word, which they learnt during the term, by themselves because the treatment appealed to them.
\end{abstract}

Keywords Corpus-Based, Collocation, Instruction, Types of Collocation

\section{Introduction}

Vocabulary was neglected after the growth of Communicative Language Teaching (CLT). Learners could communicate but misunderstanding was inevitable because of lack of knowledge of vocabulary, its collocation and pragmatic collocations. So a lot of researchers' attention was drawn to vocabulary teaching and its collocation. Afterward they came to this truth that lack of knowledge of collocation can prevent learners from inferring, and they also misunderstand native speakers. Wrong use of collocation can cause native speakers not to comprehend what the learners say. According to Zarie and Gholami (2007), another problem of second language learners is the function of near-synonyms, particularly their collocations. Near-synonyms are pairs of words with parallel meanings, but diverse collocations. Strong and powerful are two cases of near-synonyms. Tea can be strong, but not powerful. The semantic dissimilarities and implications of synonyms are not effortlessly distinguished and often fall short to be learned by second language learners (L2). Therefore, this study aspired to examine the fabrication and understanding of collocations of near synonyms. Two studies, Lien (2003) and Hsu \& Hsu (2007) have examined whether the direct teaching of lexical collocations increases EFL students 'general language fluency. They will show how collocation instruction has positive impact on the learners 'language skills. Efforts will be made to conduct follow-up research, presenting a thorough picture of how collocation instruction will promote another language skill. To help learners to sound more native-like and comprehend films, books and native speakers, and be more comprehensible, collocation has been taken into consideration. Here in this study the impact of the corpus-based collocation instruction on learning collocations is being declared.

Corpus-based collocation instruction, the collocations which are seen in different texts frequently and are fixed pairs that must be learnt to be able to communicate better, was given to experimental group within 15 session and collocations were followed by some practice to make the learners learn and use the words and their collocations in case they will sound more native-like and understand native-speakers well enough. Teaching corpus-based collocation was the variable which was worked on in this study to discover its effect on learning collocation and its impact on acquiring English as a foreign or second language to communicate. At the end of this study it was apparent that the treatment was worthy as the mean score of the experimental group was 4.93333 points higher than that of 
the control group.

\section{Review of Literature}

The word collocation is a relatively new to the lexicon of English. Collocations are defined as ordered word phrases which attach together and appear repeatedly in the usage of English. Jack Richards (1983) considered that where segmentation is complicated, comprehension is difficult as well. Some lexical and communicative qualifications studies were designed based on the key ideology of L2 vocabulary learning. It is shown here that collocations are really worth the attention of linguists and language educators.

Nattinger (1988) continued that collocations are practical in raising comprehension for the associations of words which support the learner in placing words in memory, and also allow people to foresee what kinds of words might be found together. Collocations are also functional for teaching language production because learners will subconsciously recognize certain lexical limitations whilst memorizing collocations. Brown and Payne (1994) elaborated five steps which are needed.

(1) Facing new words

(2) Obtaining the word form

(3) Getting the word meaning

(4) Merging word form and meaning in memory

(5) Using the word.

Farghal and Obiedat (1995) and Lewis (1993, 1997) particularly believed that the knowledge of collocations is of great weight and identified this as prerequisite and crucial in knowing a word. Collocations can be defined in various ways, but the most normal definition of collocations is the trend of one word to occur with one or more other words in a fossilized or quite fossilized combinations. Cowie and Howarth's model (1996) claimed that there can be a range including four categories of collocations:

1) Restricted collocations: a restricted collocation is more constrained in the selection of compositional prerequisites. (Take photos)

2) Free combinations: the meaning of free combination is interpreted from the literal meaning of single elements. (Close a window).

3) Pure idioms: a pure idiom is an individual unit whose meaning is totally unpredictable from the elements. (Spill the beans)

4) Figurative idioms: a figurative idiom has a metaphorical meaning as a group that can in some way inform its literal explanation. (Tell some body's ear off).

It is apparent that the aforementioned information focuses on collocations and idioms that are word pairs. Empirical studies on the knowledge of collocations among different groups of ESL or EFL learners disclose that learners encounter particular trouble in producing suitable word combinations because of their lack of collocation knowledge (Howarth, 1998). According to Hermann (2003), and Zareva et al. (2005), the knowledge of word has been known as a significant issue in language proficiency. Hunt and Beglar (2005) believed that the main element of language comprehension and use is the lexicon. Although it has recently gained its importance in different aspects of learning second language, it still needs more work. Smith (2005) stated collocation must be included in the curriculum. According to Forquera (2006), collocation knowledge can also enhance second language learners' mental word list and help learners' memory. It is mostly approved that collocations play a crucial role in second language learning, chiefly at the intermediate and advanced levels equivalent of L1 collocation. Her study demonstrated that even L2 advanced learners have complexities using collocations. Another study that showed the problems language learners face while learning English collocations is Koosha and Jafarpour's study, which was done on 200 Iranian university students in three Universities majoring in English in Shahrekord (2006).

The participants were then randomly divided into two groups. One group undertook the conservative treatment on prepositions and their collocational patterns in which prepositions and their collocational patterns were explicitly taught to the learners in English or Farsi. The second group, experimental one, received a data driven-based treatment that was based on concordancing lines presented in KWIC method. Two completion tests on collocation of prepositions were managed as the pre-test and post-test to check the impact of the treatments. According to Durrant (2008), using collocations is almost certainly the most significant component of turning passive words into active ones; hence, collocation is a vital part in the acquisition of a creative language system. Shehata, (2008) declared that the term collocation is initiated from the Latin verb collocare, which means to set in order/to assemble. Hashemi (2012) in his research came to this conclusion that EFL College students (English majors and non-English majors), high school students, and professors are short of collocational knowledge because collocation has been ignored in EFL classrooms. Although studies on learners' use and knowledge of collocations are admired among EFL and ESL researchers, such attractiveness is still not noticeable in the Malaysian context. The majority of EFL learners, to some extent, have adequate knowledge of English grammar and vocabulary, though they seem to have serious difficulties with using collocation in communication. For example; 'take risk' is an acceptable collocation in the English language. Iranian learners who speak Persian utter "Risk Kardan" which literally means "do risk" and when it comes to English they consider in their L1 and in place of "Take risk" they write or say "do risk." Literally, Iranians say "Do risk" while English speakers say "Take risk". So that is to say, to develop learners' reading, writing and speaking competence, they need to use collocation in their writing and speaking. So we think that it would be valuable to explore the effect of a relatively new vocabulary teaching procedure, teaching words throughout collocations in primary EFL classes. 
In Iran, great prominence is on grammar not vocabulary during any EFL course. Students and perhaps teachers themselves are not alert of word groupings. Students learn the words separately and memorize the words individually by translating them to their mother tongue. Therefore, when students want to construct collocations they fail to produce them properly and figure them out in contexts. Knowing vocabulary and its collocation enables students to speak about things and to do things. Collocations, even though are combinations of at least two words, display a degree of syntactic resistance to lexical substitution; they are semantically apparent; and therefore they are not idioms. There are linguists who do not distinguish between idioms and collocations. Idioms falling into the area of clear stereotypes are called 'restricted collocations', e.g. 'Pleased to meet you', 'be honest with', 'and use up'. Ying (2009) carried out a study on Chinese L2 learners He endeavored at probing the relation between coherence and collocations in writing. He ended that there is a relationship between the correct use of collocations and coherence in writing. To conquer the problem, collocational knowledge of L2 learners should be expanded to increase L2 proficiency. Consequently, writing will develop into more fluent, accurate, and significant because the learner knows collocations needed for writing. Gledhill, C. (2011) claimed that collocation is fundamentally word-oriented and unified. It refers to the degree to which the occurrence and connotation of a word fit together or relies on the existence of another word (or words) in the same broaden of text. Hashemi (2012) in his research came to this conclusion that EFL College students (English majors and non-English majors), high school students, and professors are short of collocational knowledge because collocation has been ignored in EFL classrooms. . Many scholars all around the world believe that students need to learn collocations to be comprehended and be able to comprehend. The main side of this study is collocation. It is claimed that learning more collocation can enhance understanding, and it helps learners sound more native-like. The aim of this article is to check how much teaching collocation affects learning them properly.

Based on abovementioned ideas it is apparent that lots of vocabulary teaching and learning researches have been done so far. It seems that proficiency in language learning is related to collocation knowledge. Collocations can be defined in various ways, but the most commonly definition of collocations is the trend of one word to co-occur with one or more other words. One significant question arises here, if we have to teach collocation to help the learners have better understanding of native-speakers or without knowing collocation, the communication is impossible. This question will be answered here.

\section{Research Questions}

One specific research question is going to be addressed in this study:

RQ: Does teaching corpus-based collocation affect learners' knowledge of collocation? Why?

\section{Research Hypotheses}

$\mathrm{H}_{0}$ : Corpus-based collocation instruction does not have any impact on EFL learners' knowledge of collocation, and the use of them.

\section{Definition of the Key Terms}

Collocation; noun; adjective; adverb; verb; preposition, corpus-based instruction

\section{Method}

\subsection{ParticipantS}

This study investigated the effect of the corpus-based collocation instruction on EFL learners' collocation learning of 60 intermediate learners through teaching corpus-based collocation to them on a 15 session treatment in Bayan and Kish institutes in Iran. They were studying English as foreign language (EFL). The average age of the participants was 22.7. The classes were randomly assigned to two groups included 30 students each. Although the classes had communicative orientation, the goal of the study was to improve the knowledge of collocation of intermediate learners, and help them use the collocations in their speech and writing. The 60 participants of the study were opted randomly (randomization). The learners had been studying in the same institutes.

\subsection{Instrument and the Study Materials}

The participants in this study were given 2tests, first the OPT test, then a collocation test one as pre-test and one as post test

\subsubsection{The OPT Test}

For conducting this research, the researcher required an OPT exam, which is a standard one, to ensure that the participants were homogenous, and it was carried out to 150 EFL students studying English as a foreign language in a language institute. The participants answered the structure, vocabulary and reading comprehension segments of the test with an utmost possible score of 50 points. Based on OPT test direction 60 intermediate students who scored $31+$ in grammar and vocabulary and $8+$ in reading section were chosen as the main sample for the present study.

The results of the OPT test for 150 students are displayed in the following table:

Table 1 depicted the results of group statistics and 
numerical information for the OPT test scores Measures of central tendency comprising the mean, the median, the mode and measures of dispersion namely the range, the variance, and the standard deviation together with measures of distribution such as Skewness and Kurtosis were displayed for the OPT test. For the present study, the main sample included 60 homogeneous participants who were selected.

Table 1. Statistics for the results of OPT test

\begin{tabular}{ccc}
\hline & \multicolumn{2}{c}{ OPT test } \\
\hline \multirow{2}{*}{$\mathrm{N}$} & Valid & 150 \\
\cline { 2 - 3 } & Missing & 0 \\
\hline Mean & 49.6667 \\
\hline Modian & 48.5000 \\
\hline Std. Deviation & 38.00 \\
\hline Variance & 17.83958 \\
\hline Skewness & 318.251 \\
\hline Std. Error of Skewness & .253 \\
\hline Kurtosis & .198 \\
\hline Std. Error of Kurtosis & -.820 \\
\hline Range & .394 \\
\hline Minimum & 71.00 \\
\hline Maximum & 19.00 \\
\hline Sum & 90.00 \\
\hline
\end{tabular}

\subsubsection{Main Study}

After the OPT test for checking the homogeneity of the students, the proficiency test which confirmed the equality of the participants in the groups, was given to them. Then it was time to administer the main study. All the participants were given the main test within two days. The administration of the treatment began the third session of the term and ended the eighteen session of the term. Before giving the tests, the participants in different groups were informed of the treatments and the relevant procedures as well. The method of teaching in the institute, where the research was being conducted, was based on Communicative Language Teaching (CLT) and the course was a conversational one. The procedures of teaching each skill was being observed properly in the institute so the control group faced with the normal phase of teaching vocabulary and as usual even the presence of the collocations were neglected let alone teaching them. Nevertheless, in the experimental group in each session of the term a few corpus-based collocations were taught. The term consists of 21 sessions. By the end of the term, which lasted about two months, the participants of both groups were tested again, so that the researcher could find if the treatment was fruitful and worthy, and if the improvement of the experimental group considerable.

\subsubsection{The Collocation Test}

A few collocations and their tests were found on the internet and some other ones were extracted from the reading itself and made by the researcher and both were checked by three raters. After being checked by three raters, it was given to the participants. The collocations were chosen carefully to ensure that no collocations were used that learners were already familiar with. Three judges evaluated the concreteness of the collocations. The collocations were excluded if the judges did not arrive at a unanimous conformity. The novelty of the collocations for the learners was checked.

Table 2. Statistics for the samples in pre and post-tests

\begin{tabular}{|c|c|c|c|c|}
\hline & $\begin{array}{c}\text { Collocation } \\
\text { test } \\
\text { (experimental } \\
\text { group, pre-test }\end{array}$ & $\begin{array}{c}\text { Collocation } \\
\text { test } \\
\text { (experimenta } \\
1 \text { group, } \\
\text { post-test }\end{array}$ & $\begin{array}{l}\text { Collocation } \\
\text { test (control } \\
\text { group, } \\
\text { pre-test) }\end{array}$ & $\begin{array}{c}\text { Collocation } \\
\text { test (control } \\
\text { group, } \\
\text { post-test) }\end{array}$ \\
\hline \multirow{2}{*}{$\mathrm{N}$} & 30 & 30 & 30 & 30 \\
\hline & 0 & 0 & 0 & 0 \\
\hline Mean & 3.3667 & 8.1833 & 3.1500 & 3.2500 \\
\hline Median & 3.2500 & 7.7500 & 3.0000 & 3.0000 \\
\hline Mode & 3.00 & 7.50 & 4.00 & $2.50 \mathrm{a}$ \\
\hline Std. Deviation & .91852 & 1.80747 & .99265 & 1.02554 \\
\hline Variance & .844 & 3.267 & .985 & 1.052 \\
\hline Skewness & .351 & .409 & .176 & .093 \\
\hline Std. Error of Skewness & .427 & .427 & .427 & .427 \\
\hline Range & 4.00 & 8.00 & 4.00 & 3.75 \\
\hline Minimum & 1.50 & 4.50 & 1.50 & 1.25 \\
\hline Maximum & 5.50 & 12.50 & 5.50 & 5.00 \\
\hline Sum & 101.00 & 245.50 & 94.50 & 97.50 \\
\hline \multicolumn{5}{|c|}{ a. Multiple modes exist. The smallest value is shown } \\
\hline
\end{tabular}




\section{Statistics for the Samples in Pre and Post-Tests}

Before running the parametric statistical tests including independent samples T-test, Skeweness analysis was done to check the normality assumption. The results of the Skewness analysis is represented in table 2. It is computed by dividing the statistic of Skewness by the standard error. The findings disclosed that the supposition of normality was fulfilled in the distribution of the scores.

Besides, one sample Komogrov- Smirnov was run to the results of the collocation tests for the both groups at pre and post-tests to confirm the normality assumption. The results are presented in the following table:

Table 3. Sample Kolmogorov Smirnov Test

\begin{tabular}{cccccc}
\hline & & $\begin{array}{c}\text { Collocation test } \\
\text { (experimental } \\
\text { group, pre-test) }\end{array}$ & $\begin{array}{c}\text { Collocation } \\
\text { test } \\
\text { (experimental } \\
\text { group, } \\
\text { post-test) }\end{array}$ & $\begin{array}{c}\text { Collocation } \\
\text { test (control } \\
\text { group, } \\
\text { pre-test) }\end{array}$ & $\begin{array}{c}\text { Collocation } \\
\text { test (control } \\
\text { group, } \\
\text { post-test) }\end{array}$ \\
\hline \multirow{2}{*}{$\begin{array}{c}\text { Most Extreme } \\
\text { Differences }\end{array}$} & Absolute & .155 & .147 & .137 & .134 \\
\cline { 2 - 6 } & Positive & .155 & .147 & .110 & .134 \\
\hline \multicolumn{2}{c}{ Negative } & -.106 & -.109 & -.137 & -.134 \\
\hline \multicolumn{2}{c}{ Test Statistic } & .155 & .147 & .137 & .134 \\
\hline \multicolumn{7}{c}{ Asymp. Sig. (2-tailed) } & .063 & .095 & .154 & .176 \\
\hline \multicolumn{7}{c}{$\begin{array}{l}\text { a. Test distribution is Normal. } \\
\text { b. Calculated from data. }\end{array}$} \\
\hline
\end{tabular}

The abovementioned table, table 3, demonstrated the probabilities of the $\mathrm{Z}$ statistics are all above 0.05 , conveying that the normality is observed in the distributions. The results of the Kolmogrov Smirnov test suggested the normality of the samples distribution.

\section{Descriptive Statistics for the Pre -Test Scores of Collocation Test}

The knowledge of collocation was scrutinized before proposing the specific treatment of corpus-based collocation teaching at the beginning of the study. An independent samples t- test was used to analyze students' scores in the pre-collocation test to examine the possible initial differences between the two groups in terms of their collocation knowledge.

Table 4. Group statistics for the control and experimental groups' pre-test collocation scores

\begin{tabular}{|c|c|c|c|c|c|c|c|c|c|c|}
\hline & & \multicolumn{3}{|c|}{ Group } & \multicolumn{2}{|c|}{$\mathrm{N}$} & Iean & Std. Deviation & \multicolumn{2}{|c|}{ Std. Error Mean } \\
\hline \multirow{2}{*}{\multicolumn{2}{|c|}{$\begin{array}{l}\text { Collocation test } \\
\text { (pre-test) }\end{array}$}} & \multicolumn{3}{|c|}{ Control } & 30 & \multicolumn{2}{|c|}{3.1500} & .99265 & \multicolumn{2}{|c|}{.18123} \\
\hline & & \multicolumn{3}{|c|}{ Experimental } & 30 & \multicolumn{2}{|c|}{3.3667} & .91852 & \multicolumn{2}{|c|}{.16770} \\
\hline \multicolumn{11}{|c|}{$\begin{array}{l}\text { Levene's } \\
\text { Test for } \\
\text { Equality } \\
\text { of } \\
\text { Variances }\end{array}$} \\
\hline & & \multirow[t]{2}{*}{$\mathrm{F}$} & \multirow[t]{2}{*}{ Sig. } & \multirow[t]{2}{*}{$\mathrm{T}$} & \multirow[t]{2}{*}{ Df } & \multirow[t]{2}{*}{$\begin{array}{c}\text { Sig. } \\
\text { (2-tailed) }\end{array}$} & \multirow[t]{2}{*}{$\begin{array}{c}\text { Mean } \\
\text { Difference }\end{array}$} & \multirow[t]{2}{*}{$\begin{array}{l}\text { Std. Error } \\
\text { Difference }\end{array}$} & \multicolumn{2}{|c|}{$\begin{array}{c}95 \% \\
\text { Confidence } \\
\text { Interval of the } \\
\text { Difference }\end{array}$} \\
\hline & & & & & & & & & Lower & Upper \\
\hline \multirow{2}{*}{$\begin{array}{c}\text { Collocation } \\
\text { test } \\
\text { (pre-test) }\end{array}$} & $\begin{array}{c}\text { Equal } \\
\text { variances } \\
\text { assumed } \\
\end{array}$ & .46 & .49 & -.87 & 58 & .384 & -.216 & .246 & -.71 & .27 \\
\hline & $\begin{array}{c}\text { Equal } \\
\text { variances } \\
\text { not } \\
\text { assumed }\end{array}$ & & & -.87 & 57.65 & .384 & -.216 & .246 & -.71 & .27 \\
\hline
\end{tabular}


As the results showed in table 4, in the abovementioned table, experimental group's mean score (mean=3.3667) was a little greater than the control group's mean score (mean=3.1500). The degree of dispersion of the collocation scores for the control group $(\mathrm{SD}=.18123)$ was larger than that of the experimental group $(\mathrm{SD}=.16770)$.

The Independent Samples T- Test procedure, as shown above in table 5, weighed up the means for the control and experimental groups. This time the outcomes revealed that there was no significant difference between the two groups with respect to their knowledge of collocation before introducing the treatment.

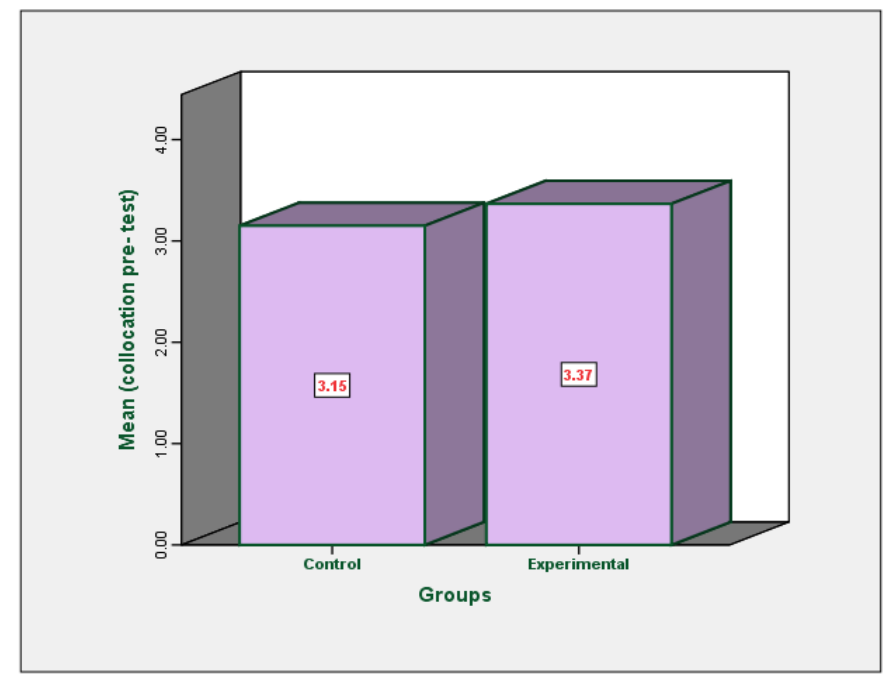

Figure 1. The comparison between the two groups on collocation pre-test at the beginning of the study

After investigating the two groups' knowledge in terms of their understanding of collocations, the specific treatment was given to the experimental group while the control group followed the traditional instruction. After practicing corpus -based collocation instruction for the experimental group, the two groups' performances on collocation test were examined to see the possible effects of collocation instruction. The results of the analyses are presented in the following table:

Table 6. Group statistics for the control and experimental groups' post-test collocation scores

\begin{tabular}{lccccc}
\hline & Group & N & Mean & Std. Deviation & Std. Error Mean \\
\hline \multirow{2}{*}{ Collocation test(post-test) } & Control & 30 & 3.2500 & 1.02554 & .18724 \\
\cline { 2 - 6 } & Experimental & 30 & 8.1833 & 1.80747 & .33000 \\
\hline
\end{tabular}

The descriptive table, table 6, illustrated the sample size, mean, standard deviation, and standard error for both control and experimental groups at the end of the study. The control and experimental group mean score were 3.2500 and 8.1833 respectively. The two groups varied some points around their average. This mean score of the experimental group was 4.93333 points higher than that of the control group. In addition, the degree of dissimilarity of the scores for the experimental group $(\mathrm{SD}=.33000)$ was slightly higher than the degree of scattering of scores around the mean score for the control group $(\mathrm{SD}=.18724)$.

Table 7. Independent Samples Test for the control and experimental groups' post-test collocation scores

\begin{tabular}{|c|c|c|c|c|c|c|c|c|c|c|}
\hline & & $\begin{array}{r}\text { Le } \\
\mathrm{Te} \\
\text { Equ } \\
\mathrm{Var}\end{array}$ & $\begin{array}{l}\text { ne's } \\
\text { for } \\
\text { ity of } \\
\text { nces }\end{array}$ & \multicolumn{7}{|c|}{ t-test for Equality of Means } \\
\hline & & \multirow[t]{2}{*}{$\mathrm{F}$} & \multirow[t]{2}{*}{ Sig. } & \multirow[t]{2}{*}{$\mathrm{T}$} & \multirow[t]{2}{*}{ Df } & \multirow[t]{2}{*}{$\begin{array}{c}\text { Sig. } \\
\text { (2-tailed) }\end{array}$} & \multirow[t]{2}{*}{$\begin{array}{c}\text { Mean } \\
\text { Difference }\end{array}$} & \multirow[t]{2}{*}{$\begin{array}{l}\text { Std. Error } \\
\text { Difference }\end{array}$} & \multicolumn{2}{|c|}{$\begin{array}{l}95 \% \text { Confidence } \\
\text { Interval of the } \\
\text { Difference }\end{array}$} \\
\hline & & & & & & & & & Lower & Upper \\
\hline \multirow{2}{*}{$\begin{array}{l}\text { Collocation } \\
\text { test(post-test) }\end{array}$} & $\begin{array}{c}\text { Equal } \\
\text { variances } \\
\text { assumed }\end{array}$ & 6.6 & .013 & -13 & 58 & .000 & -4.93 & .379 & -5.69 & -4.17 \\
\hline & $\begin{array}{c}\text { Equal } \\
\text { variances } \\
\text { not } \\
\text { assumed }\end{array}$ & & & -13 & 45.91 & .000 & -4.93 & .379 & -5.69 & -4.16 \\
\hline
\end{tabular}


Additionally, in table 7, the independent sample T-test procedure introduced two tests of the difference between the control and experimental groups. This time the Levene statistic tested the equality of the variances and it was reported that the significance value of the statistic was equal to .013 . Since this approximation was lower than 0.05 , it could be supposed that the groups did not have uniform variances and thus the second test was considered. In fact, learners' performance in the experimental group (Mean =8.1833) weighed more than that of the control group (Mean =3.2500) in posttest of collation test. Since the subjects were randomly assigned to two groups so that the difference found in their post- test was not due to chance and it could be related to the specific treatment of corpus based collocation instruction employed for the experimental group. Consequently, the null hypothesis is rejected implying that corpus-based collocation affects learners' knowledge of collocation.

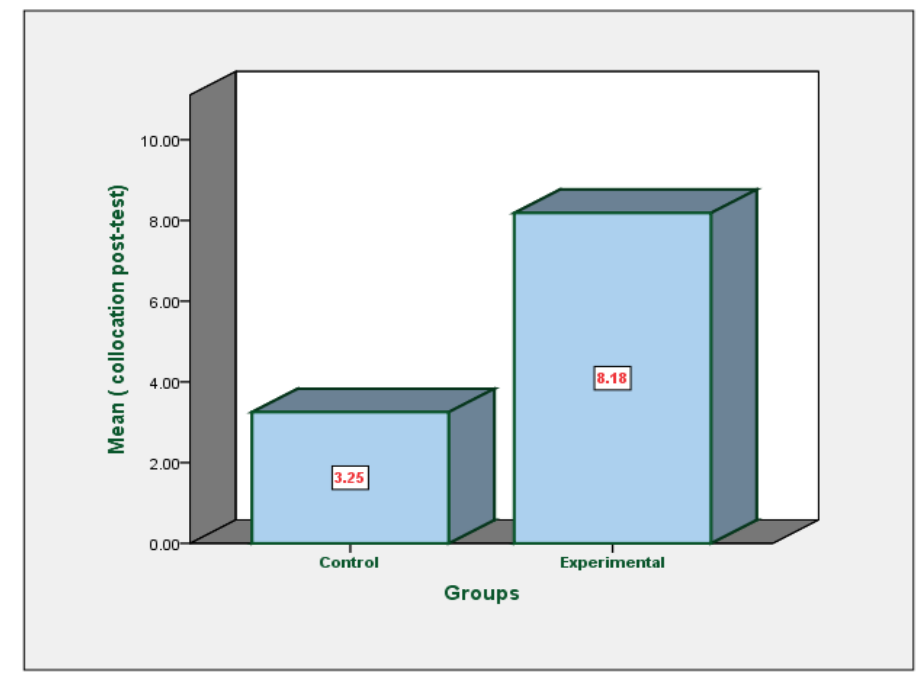

Figure 2. The comparison between the two groups on collocation post-test at the end of the study

In order to investigate students' progress within groups, two paired t-tests were also run, which showed the subjects' possible progress in pre-test and post-test. That is being described in the following section.

Table.8. Paired Samples Statistics

\begin{tabular}{|c|c|c|c|c|c|}
\hline & & Mean & $\mathrm{N}$ & Std. Deviation & $\begin{array}{c}\text { Std. Error } \\
\text { Mean }\end{array}$ \\
\hline \multirow[b]{2}{*}{ Pair 2} & Collocation test( experimental group, pre-test) & 3.3667 & 30 & .91852 & .16770 \\
\hline & Collocation test( experimental group, post-test) & 8.1833 & 30 & 1.80747 & .33000 \\
\hline \multirow{2}{*}{ Pair 4} & Collocation test( control group, pre-test) & 3.1500 & 30 & .99265 & .18123 \\
\hline & Collocation test ( control group, post-test) & 3.2500 & 30 & 1.02554 & .18724 \\
\hline
\end{tabular}

In table 8 , as regards collocation test, the mean score of the experimental group has improved from 3.3667 in pre- test to 8.1833 in post- test; that of the control group has changed from 3.1500 in pre- test to 3.2500 in post- test.

Table.9. Paired samples test for collocation tests

\begin{tabular}{|c|c|c|c|c|c|c|c|c|c|}
\hline & & \multicolumn{5}{|c|}{ Paired Differences } & \multirow{3}{*}{$\mathrm{T}$} & \multirow{3}{*}{ df } & \multirow{3}{*}{$\begin{array}{c}\text { Sig. } \\
\text { (2-tailed) }\end{array}$} \\
\hline & & \multirow{2}{*}{ Mean } & \multirow{2}{*}{$\begin{array}{l}\text { Std. } \\
\text { Deviat } \\
\text { ion }\end{array}$} & \multirow{2}{*}{$\begin{array}{l}\text { Std. Error } \\
\text { Mean }\end{array}$} & \multicolumn{2}{|c|}{$\begin{array}{c}95 \% \text { Confidence Interval } \\
\text { of the Difference }\end{array}$} & & & \\
\hline & & & & & Lower & Upper & & & \\
\hline Pair 2 & $\begin{array}{c}\text { Collocation test( experimental } \\
\text { group , pre-test) - Collocation } \\
\text { test(experimental group } \\
\text { post-test) }\end{array}$ & -4.816 & .89 & .163 & -5.15 & -4.48 & -29.46 & 29 & .00 \\
\hline Pair 4 & $\begin{array}{l}\text { Collocation test( control group, } \\
\text { pre-test) - Collocation } \\
\text { test( control group, post-test) }\end{array}$ & -.100 & .45 & .083 & -.27 & .07 & -1.19 & 29 & .24 \\
\hline
\end{tabular}


As it was depicted in the tables 8 and 9 both control and experimental groups had preceded in the post-tests of collocation tests. Based on the results of paired samples T-tests, this improvement was statistically significant simply for the experimental group in both tests but not for the control group (P experimental group (collocation test) $<0.05, \mathrm{P}$ control group (collocation test) $\geq 0.05$ ). In other words, the experimental group made a noticeably higher advance as differentiated to the control group in the collocation tests.

\section{Result}

The major goal of the present research was to investigate the effects of corpus-based collocation instruction on Iranian EFL learners' knowledge of collocation to prove that teaching corpus-based collocation can assist learners in learning and using collocations better in comparison with the traditional instruction. The major problem was unawareness of the learners of the existence of collocations, and their inability to recognize and to use them. The researcher's attention was drawn to this case, and she work on this item to shed a light to help the teachers teach corpus-based collocations to make the learners learn the collocations better and more efficiently. Therefore A total number of sixty EFL learners were selected based on their performance on OPT test. Then they were randomly divided into two groups each containing thirty subjects. The knowledge of collocation was also examined before proposing the specific treatment of corpus-based collocation teaching at the beginning of the study. An independent samples t- test was used to analyze students' scores in the pre-collocation test to examine the possible initial differences between the two groups in terms of their collocation knowledge. The Independent Samples TTest procedure weighed up the means for the control and experimental groups. This time the outcomes revealed that there was no significant difference between the two groups with respect to their knowledge of collocation.

Before introducing the treatment after investigating the two groups' knowledge in terms of their understanding of collocations, the specific treatment was given to the experimental group while the control group followed the traditional instruction (placebo one). After practicing corpus -based collocation instruction for the experimental group, the two groups' performances on collocation test were examined to see the possible effects of collocation instruction. Additionally, the independent sample T-test procedure introduced two tests of the difference between the control and experimental groups. This time the Levene statistic tested the equality of the variances and it was reported that the significance value of the statistic was equal to .013. Since this approximation was lower than 0.05 , it could be supposed that the groups did not have uniform variances and thus the second test was considered. In fact, learners' performance in the experimental group (Mean $=8.1833$ ) weighed more than that of the control group (Mean $=3.2500)$ in posttest of collation test. Since the subjects were randomly assigned to two groups so that the difference found in their post- test was not due to chance and it could be related to the specific treatment of corpus based collocation instruction employed for the experimental group. Consequently, the null hypothesis is rejected implying that corpus-based collocation affects learners' knowledge of collocation. In sum, teaching corpus-based collocations is beneficial for EFL learners' collocation learning. The learners in the experimental group of this study learnt the collocations practically, and they could also use them while writing or speaking. Collocation test was done properly by them. They were also appealed to finding collocation of each word and learning them perfectly.

\section{Discussions}

This section provides a specific discussion for the research question and makes endeavor to link the findings to the existing literature. The findings of this study showed that the experimental group, which received corpus-based instruction outperformed better in learning collocation. Lack of knowledge of collocation was the problem which draws the researcher's attention. Unfortunately some English teachers themselves are unaware of the existence of collocations, so the learners knew nothing about collocations and their significance and usage. The researcher decided to work on this field to shed a light on the importance of the collocations and recommending a suitable way to make the learning easier. As mentioned in literature review, Second language acquisition researchers believe that vocabulary learning is the most important aspect of second language teaching; therefore it is essential for teachers to assist learners in learning strategies to expand their knowledge of collocation and help them use the collocations in their speaking and writing. This article is in line with some other scholars such as Hunt and Beglar (2005) who believed that the main element of language comprehension and use is the lexicon. Although it has recently gained its importance in different aspects of learning second language, it still needs more work.

Smith (2005) stated collocation must be included in the curriculum. According to Durrant (2008), using collocations is almost certainly the most significant component of turning passive words into active ones; hence, collocation is a vital part in the acquisition of a creative language system. Shehata, (2008) declared that the term collocation is initiated from the Latin verb collocare, which means to set in order/to assemble. All these studies were in line with our study which demonstrated and proved that teaching corpus-based collocations had a positive effect on collocation learning and awareness. In this term, this study used corpus-based collocation instruction to teach collocations to make comprehension more possible. This study displayed that learning collocations in this way was very beneficial, and it made communication much easier and more native-like.

It was apparent that teaching corpus-based collocation and 
arousing learners' awareness could also help learners get familiar with the language socioliguistically and pragmatically. Pragmatic is the study of the use of language in communication, particularly the relationships between sentences and the context in which they are used. Pragmatic collocations are the ones which should have been taken into consideration, and if they are not learnt, misunderstanding will occur. Since it is apparent from abovementioned findings that vocabulary and its collocation must receive double consideration, and according to the article corpus-based collocation instruction can assist learners in learning communicative English better, and can also make them sound more native-like.

\section{Conclusions}

\subsection{Pedagogical Implications}

The present study scrutinized the effects of corpus-based collocation instruction on 60 Iranian EFL learners, who were studying communicative English in two institutes in Iran The quantitative data indicated that (1) corpus-based collocation instruction improves the subjects' collocation learning more than single word instruction. Corpus-based collocation instruction could be valuable to explore as a teaching option although follow up instructional study needs to be carried out to further support the findings. This study came to the conclusion that teaching lexical collocation has a constructive effect on collocational knowledge of the students, so it is recommended that teachers and material designers adjust their curriculum to encompass the teaching of lexical collocations into their present practices. The new words should not be presented as single-item vocabularies. It is better to present them as collocation, at least with one or two more items. Teachers ought to make their students familiar with the notion of collocation, teach different types of collocation to them, and raise their awareness of such combinations through different exercises such as highlighting.

This may entail that explicit collocation instruction is necessary to improve EFL/ESL learners" knowledge of collocation. This result seems to confirm previous scholars' propositions concerning the following aspects. First, vocabulary should be taught collocationally rather than individually. The findings of the present study give support to the previous scholars who all underscore the outcome of collocations on language skills. The mean score of the two groups justifies that the treatment was worthwhile as the learners in the experimental group were able to use the collocations learnt properly. They were also very aware of the existence of collocations which were unidentified at the beginning of the study, and had been neglected during the terms they had been learning English. Therefore this study can help authors and teachers take teaching corpus-based collocations into serious consideration so authors will try to open a space for teaching and practicing collocations in their books. This can not only help second language learners read and write better but also hear and communicate better.

\section{Innovation of this Study}

Having announced the novelty and innovation of this study, we will utter that it will increase the quantity of learners' mental interaction, and it can also devise a new way how to enhance comprehension without using equipment such as dictionaries, CDs, etc. so it is so economical. It also boosts the co-relation among words, cohesion, coherence, and the use of their schemata in cognitive language proficiency. It can also shed a light on translation to make the pre-service translators know the magnitude of collocation in figuring out the meaning and conveying the meaning in the translated script better. Henceforward the practitioners, the teachers, will pay double attention to teaching collocation and endeavor to draw the learners' attention to them and help to learn them more efficiently.

\section{REFERENCES}

[1] Brown, C., \& Payne, M. E. (1994). Five Essential Steps of Processes in Vocabulary Learning. Paper presented at the TESOL Convention, Baltimore.

[2] Cowie, A. (1988). Stable and creative aspects of vocabulary use. In R. Carter and M. McCarthy (eds.): Vocabulary and Language Teaching, London: Longman: 126-139.

[3] Cowie, A. P., \& Howarth, P. (1996). Phraseological competence and written proficiency. In G. M. Blue \& R. Mitchell (eds.), Language and education, 11, 80-93. Clevendon: Multilingual Matters.

[4] Durrant, P. L. (2008). High-Frequency Collocations And Second Language Learning. (Unpublished doctoral dissertation). University of Nottingham, UK. Retrieved May 6, 2008 from http://etheses.nottingham.ac.uk/622/

[5] Farghal, M., \& Obiedant, H. (1995). Collocations: a Neglected Variable in EFL. IRAL, 33(4), 315-331. http://dx.doi.org/10.1515/iral.1995.33.4.315

[6] Forquera, D. (2006, August). Goodbye Foreign Flavour. The Hows and Whys of Teaching Collocation. Paper presented at the Second National Meeting of Teacher Training Colleges. March 2, 2008, from http://www.danielaforquera. com.ar/docs/Hanodut.pdf

[7] Gledhill, C. (2011), "The 'Lexicogrammar' Approach to Analysing Phraseology and Collocation in ESP Texts", in ASP 59: $5-23$

[8] Hashemi, M., Azizinezhad, M. \& Dravishi, S. 2012. Collocation a neglected aspect in teaching and learning EFL. Procedia-Social and Behavioral Sciences 31: 522-525.

[9] Hermann, F. (2003). Differential effects of reading and memorization of paired associates on vocabulary acquisition 
in adult learners of English as a second language. TESL-EJ:Teaching English as a second or foreign language, 7(1), 1-16. [online]

$<$ http://wwwwriting.berkeley.edu/tesl-ej/ej25/a1.html> [Sept. 2006] Papers from the Nineteenth International Conference on English Language Research on Computerised Corpora (ICAME 1998) (pp. 17-32). Amsterdam: Rodopi.

[10] Howarth, P. (1998a). The phraseology of learners' academic writing. In A. P. Cowie (Ed.), Phraseology: Theory, analysis and applications. (pp. 161-186). Oxford, UK: Clarendon Press.

[11] Hsu, J-Y., \& Hsu, L-C. (2007). Teaching lexical collocations to enhance listening comprehension of English majors in a technological university of Taiwan. Soochow Journal of Foreign Languages \& Cultures, 24, 1-32.

[12] Hunt, A., \& Beglar, D. (2005). A Framework for Developing EFL Vocabulary. Reading a Foreign Language, 17 (1).

[13] Lewis, M. (1993). The lexical approach: The state of ELT and a way forward. Hove: Language Teaching Publications.

[14] Lewis, M. (1997). Implementing the lexical approach: Putting theories into practice. London: Language Teaching Publications.

[15] Lewis, M. (2000). Teaching Collocation: Further Developments in the Lexical Approach. Teaching English as a Second or Foreign Language, 4 (4).

[16] Lien, H-Y. (2003). The effects of collocation instruction on the reading comprehension of Taiwanese college students.
Unpublished doctoral dissertation, Indiana University of Pennsylvania, Pennsylvania.

[17] Koosha, M., \& Jafarpour, A. (2006). Data- Driven Learning and Teaching Collocation of Prepositions: the Case Study of Iranian EFL Adult Learners, Asian EFL Journal, 8(4), 192-209. [Online] Available: http://www.asian-efl-journal.co m/Dec_06_mk\&aaj.php (August 4, 2010)

[18] Nattinger, J. 1988. Some current trends in vocabulary teaching. Vocabulary and language teaching: 60-82.

[19] Richards, J. C. (1983). Listening comprehension: Approach, design, procedure. TESOL Quarterly 17.2, 219-239.

[20] Shehata, A. (2008). L1 Influence on the Reception and Production of Collocations bym Advanced ESL/EFL Arabic Learners of English. [Online] Available: http://etd.ohiolink.edu/view.cgi/Shehata/Asmaa/K.pdf?ohiou 1218237449.(October 4, 2010)

[21] Smith, C. 2005. The lexical approach: Collocation in high school English language learners. George Fox University.

[22] Ying, S. (2009). Study on collocations in English writing by Chinese students. Journal of Sino-US English Teaching, 6(3), 25-30.

[23] Zareva, A. (2005). Models of lexical knowledge assessment of second language learners of English at higher levels of language proficiency. System, 33, 547-562.

[24] Zarei, A. A., \& Golami, V. (2007). The effect of partial synonymy on L2 vocabulary learning, Iranian Journal of Language Studies, 1(2), 73-88. 